\title{
Anti-inflammatory activity in selected Antarctic benthic organisms
}

\author{
Juan Moles ${ }^{1 *}$, Anna Torrent ${ }^{2}$, M. José Alcaraz ${ }^{3}$, Ramon Ruhí $^{2}$ and Conxita Avila ${ }^{1}$ \\ ${ }^{1}$ Department of Animal Biology (Invertebrates), Biodiversity Research Institute (IrBIO), Universitat de Barcelona, Barcelona, Catalonia, Spain \\ ${ }^{2}$ R\&D Department, Bioibérica, Barcelona, Catalonia, Spain \\ ${ }^{3}$ Department of Pharmacology and Pharmacodynamics, University of Valencia, Valencia, Spain
}

\section{Edited by:}

Donatella De Pascale, National

Research Council- CNR, Italy

Reviewed by:

Maria Rosaria Coscia, National

Research Council of Italy, Italy

Giovanna Romano, Stazione

Zoologica Anton Dohrn, Italy

*Correspondence:

Juan Moles, Department of Animal

Biology (Invertebrates), Biodiversity

Research Institute (IrBIO),

Universitat de Barcelona,

Av. Diagonal 643, 08028 Barcelona

Catalonia, Spain

e-mail:moles.sanchez@gmail.com
Antarctic benthos was prospected in search for anti-inflammatory activity in polar benthic invertebrates, in two different geographical areas: deep-bottoms of the Eastern Weddell Sea and shallow-waters of the South Shetland Islands. A total of 36 benthic algae and invertebrate species were selected to perform solubility tests in order to obtain extracts that were soluble at an innocuous ethanol concentration (0.2\%) for cell culture, and further test them for anti-inflammatory activity. From these, ethanol extracts of ten species from five different phyla resulted suitable to be studied in cell macrophage cultures (RAW 264.7). Cytotoxicity (MTT method) and production of inflammatory mediators (prostaglandin $E_{2}$, leukotriene $B_{4}$, interleukin-1 $\beta$ ) were determined at three extract concentrations $(50,125,250 \mu \mathrm{g} / \mathrm{mL})$. Bioassays resulted in four different species showing anti-inflammatory activity corresponding to three sponges: Mycale (Oxymycale) acerata, Isodictya erinacea, and I. toxophila; and one hemichordate: Cephalodiscus sp. These results show that Antarctic sessile invertebrates may have great value as a source of lead compounds with potential pharmaceutical applications.

Keywords: inflammatory inhibitor, Antarctic benthic invertebrates, sponge, hemichordate, marine natural products

\section{INTRODUCTION}

The Ocean harbors a rich source of both biological and chemical diversity. Although this diversity is the source of unique chemical compounds, its potential for pharmaceutical applications remains still underexplored (Kijjoa and Sawangwong, 2004; Albericio et al., 2010). Some marine natural products show useful pharmacological activities and are being developed either as analgesics or to treat inflammation (Jha and Zi-rong, 2004; Mayer et al., 2011). Many sessile and soft bodied benthic organisms possess defensive mechanisms based on the use of chemical compounds, which often display high biological activity (Faulkner, 1995). Recent studies on marine organisms are in fact providing many bioactive natural products, in larger percentages than terrestrial organisms (König et al., 2006; Newman and Cragg, 2012). In particular, organisms from temperate and tropical areas have been the most studied so far, while polar organisms remain almost unknown (Lebar et al., 2007; Avila et al., 2008; Blunt et al., 2013). During several cruises in the Southern Ocean we collected samples of benthic sessile and sluggish organisms in order to evaluate their potential for pharmacological applications. Thus, the aim of this study was to determine the potential anti-inflammatory and pain-killer applications of some Antarctic samples collected in the Eastern Weddell Sea and the South Shetland Islands. In order to do this, we tested the possible inhibition of the production of some important mediators of inflammation and pain. We tested ethanol (EtOH) extracts at different concentrations as a source of natural products from marine organisms. Since inflammation is caused by the release of chemicals from tissues and migrating cells
(Korbut and Guzik, 2011), we decided to test the release of some of the most strongly implicated compounds in the inflammation reaction: the prostaglandins (PGs), leukotrienes (LTs), and interleukin-1 (IL-1).

\section{MATERIALS AND METHODS SAMPLE COLLECTION}

Marine benthic invertebrate samples were collected in the Eastern Weddell Sea (Antarctica) during the ANT XXI/2 cruise (November 2003-January 2004) on board the R/V "Polarstern" (AWI, Bremerhaven, Germany). Our samples were obtained from 7 stations at depths ranging from 230 to $600 \mathrm{~m}$ sampled with Agassiz and bottom trawls. During ACTIQUIM-I campaigns (2007-2008 and 2008-2009), algae and invertebrate samples from Deception, Livingston, and Snow Islands were sampled by SCUBA at 7 stations (ca. $0-15 \mathrm{~m}$ depth) (Table 1). Organisms were photographed alive and immediately frozen $\left(-20^{\circ} \mathrm{C}\right)$ for chemical investigations. Organisms were selected according to potential interest based on ecological observations and/or previous ecological assays (Taboada et al., 2012). Voucher specimens or a portion of each sample was fixed in 10\% formalin or $70 \% \mathrm{EtOH}$ for taxonomical identification. These vouchers are deposited at the Dept. of Animal Biology (Invertebrates), University of Barcelona, Spain.

\section{CHEMICAL EXTRACTION AND SOLUBILITY SCREENING}

When necessary, several conspecific specimens from the same station were extracted together in order to obtain enough extract 
Table 1 | Data of the benthic algae and invertebrates used in this study, collected in the Weddell Sea and the vicinities of the South Shetland Islands (Deception, Livingston, and Snow Islands) during ANT XXI/2, ACTIQUIM-1, and ACTIQUIM-2 cruises.



AGT, Agassiz trawl; BT, bottom trawl; SD, scuba diving. * Species selected for the anti-inflammatory assays according to their solubility in ethanol. 
for the experiments. Frozen selected samples were weighted and immediately lyophilized for 24-48 h. Subsequently, dehydrated samples were re-weighted, pounded, and exhaustively extracted with absolute ethanol $(1: 10 \mathrm{w} / \mathrm{v})$ helping with ultrasonic baths of $10 \mathrm{~min}$. After filtering, the ethanol of the remaining extracts was evaporated in vacuo. The solid ethanol extracts were sequentially solubilized at different EtOH/ $\mathrm{H}_{2} \mathrm{O}$ concentrations: $125 \mu \mathrm{g} / \mu \mathrm{L}$ $\mathrm{EtOH} 100 \%, 5 \mu \mathrm{g} / \mu \mathrm{L}$ EtOH $4 \%$, and $0.25 \mu \mathrm{g} / \mu \mathrm{L}$ EtOH $0.2 \%$ and freeze-dried immediately. Cell culture was performed only with ethanol extracts that remained soluble at $\mathrm{EtOH} 0.2 \%$, as it is the highest ethanol concentration innocuous to cells. Ten species with soluble extracts at $0.2 \% \mathrm{EtOH}$ were chosen to perform anti-inflammatory assays according to the solubility tests. We similarly extracted more individuals and/or the rest of the frozen samples selected in order to obtain enough extract for the anti-inflammatory assays. Infrared spectra of samples and replicates were performed for all the species in order to discard contamination due to extraction methods of the ten species. Wet, dry, and extract's weight of the species selected and those rejected are shown in Supplementary Tables S1, S2, respectively.

\section{CELL CULTURE}

The mouse macrophage RAW 264.7 cell line (American Type Culture Collection, Manassas, VA, U.S.A.) was cultured in DMEM medium supplemented with 5\% fetal bovine serum. Cells were incubated with marine organisms' extracts at concentrations of 50,125 , and $250 \mu \mathrm{g} / \mathrm{mL}$ (dissolved in $0.2 \%$ ethanol). The cells were stimulated with lipopolysaccharide (LPS; $1 \mu \mathrm{g} / \mathrm{ml}$ ) and incubated for $24 \mathrm{~h}$, in the presence or absence of extracts. Dexamethasone $(1 \mu \mathrm{M})$ was used as a reference anti-inflammatory drug. Each test was performed in quadruplicate. Toxicity of the extracts at the concentrations tested was assessed by the mitochondrial-dependent reduction of 3-(4,5dimethylthiazol-2-yl)-2,5 diphenyltetrazolium bromide to colored formazan (MTT method). The production of inflammatory mediators was determined in cell supernatants by measuring: prostaglandin $\mathrm{E}_{2}\left(\mathrm{PGE}_{2}\right)$ and leukotriene $\mathrm{B}_{4}\left(\mathrm{LTB}_{4}\right)$ by radioimmunoassay and interleukin-1 $\beta$ (IL- $1 \beta$ ) by ELISA. Statistical significance was established by ANOVA followed by Dunnett's test. Results indicate mean $\pm \mathrm{SE}$ (at least $n=8$ for each group). ${ }^{*} P<$ $0.05,{ }^{* *} P<0.01$ with respect to LPS control.

\section{RESULTS}

\section{SOLUBILITY TESTS}

A total of 36 ethanol extracts from benthic algae and invertebrates were dissolved at decreasing ethanol concentrations, down to $0.2 \% \mathrm{EtOH}$, to perform the bioactivity assays at an innocuous ethanol concentration (Table 1). Ethanol extracts of ten species from five different phyla: Achrophyta (2), Porifera (4), Chordata (2), Echinodermata (1), and Hemichordata (1), resulted suitable, i.e., soluble at EtOH 0.2\%, to cell culture (asterisks in Table 1).

\section{CYTOTOXICITY}

EtOH extracts of the alga Desmarestia menziesii, the sponge Mycale (Oxymycale) acerata, and the seastar Odontaster validus exhibit cytotoxicity at the two higher concentrations (125 and $250 \mu \mathrm{g} / \mathrm{mL}$; Figure 1). Certain cytotoxicity, only at the highest concentration, was found in the alga Desmarestia anceps, the sponge Isodictya toxophila, and the hemichordate Cephalodiscus sp. Finally, the sponges Isodictya erinacea and Homaxinella cf. balfourensis, the ascidiacean Synoicum adareanum, and the thaliacean Salpa cf. thompsoni were not cytotoxic at the concentrations tested.

\section{RELEASE OF INFLAMMATORY MEDIATORS}

Desmarestia menziesii extracts decreased the release of IL- $1 \beta$ and $\mathrm{PGE}_{2}$ at cytotoxic concentrations (Supplementary Figure S1). Similarly, the extract of Odontaster validus reduced the release of IL-1 $\beta$ at the highest concentration, which had cytotoxic effects. The EtOH extract of the brown alga $D$. anceps inhibited $\mathrm{PGE}_{2}$ release at non-cytotoxic concentrations $(50$ and $125 \mu \mathrm{g} / \mathrm{mL})$, while showing no action on the other mediators. The extract of the salpid Salpa cf. thompsoni reduced significantly and dosedependently the release of IL- $1 \beta$ and $\mathrm{PGE}_{2}$. However, at the highest concentration $(250 \mu \mathrm{g} / \mathrm{mL})$ increased the release of $\mathrm{LTB}_{4}$. The EtOH extract of the demosponge Homaxinella cf. balfourensis reduced significantly the release of IL- $1 \beta$ and $\mathrm{PGE}_{2}$ only at the highest, but not cytotoxic, concentration $(250 \mu \mathrm{g} / \mathrm{mL})$. Finally, the extract of the colonial ascidiacean, Synoicum adareanum, increased the release of $\mathrm{PGE}_{2}$ and $\mathrm{LTB}_{4}$ at the highest concentration, having no effect at lower concentrations (Supplementary Figure S1).

The extract of Isodictya erinacea inhibited significantly and dose-dependently the release of IL- $1 \beta$ and $\mathrm{PGE}_{2}$, although not affecting $\mathrm{LTB}_{4}$ (Figure 1). The extracts of both the sponge Isodictya toxophila and the hemichordate Cephalodiscus sp. decreased the release of IL- $1 \beta$ and $\mathrm{LTB}_{4}$ at two non-cytotoxic concentrations (50 and $125 \mu \mathrm{g} / \mathrm{mL}$ ) and also diminished $\mathrm{PGE}_{2}$ release at the intermediate concentration $(125 \mu \mathrm{g} / \mathrm{mL})$ (Figure 1). Mycale (Oxymycale) acerata's extract decreased the release of $\mathrm{IL}-1 \beta, \mathrm{PGE}_{2}$, and $\mathrm{LTB}_{4}$ at the lower concentration of $50 \mu \mathrm{g} / \mathrm{mL}$, which was not cytotoxic (Figure 1).

\section{DISCUSSION}

Cytotoxicity was determined in order to evaluate the possible further applications as anti-inflammatory activity. Among the three species which exhibit more cytotoxic activity two were previously investigated. The brown macroalgae Desmarestia menziesii is known to produce plastoquinones, which have been suggested to present cytotoxic activity against leukemia cells, toxicity to fish, and inhibit mitosis of fertilized sea urchin eggs (Rivera, 1996). Also Mycale (Oxymycale) acerata is a chemically bioactive species displaying cytotoxicity to sea urchin gametes (McClintock et al., 1990). However, the sea star Odontaster validus is here reported as a cytotoxic species for the first time.

The species with intermediate cytotoxicity, i.e., only at the highest concentration, have been reported previously with similar cytotoxic activity. Desmarestia anceps possess antibacterial and diatom's antifouling activity (Laturnus et al., 1996; Huang et al., 2006). Cytotoxicity against cells of human colon adenocarcinoma was recently proved in the deep-sea sponge Isodictya toxophila (Turk et al., 2013). Several studies in equatorial waters showed that isolates from Cephalodiscus gilchristi, the cephalostatins, 

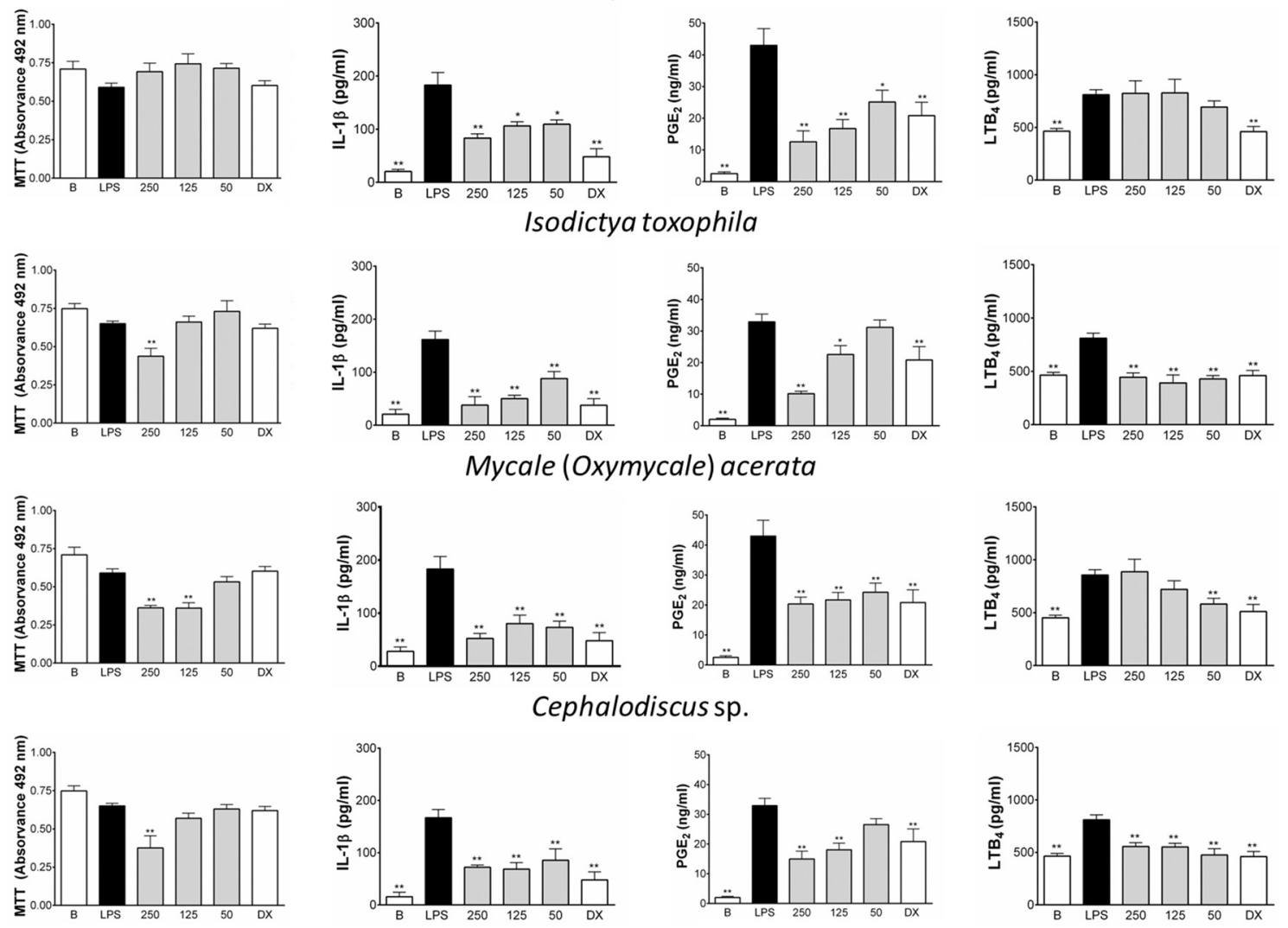

FIGURE 1 | Toxicity and anti-inflammatory effects of the extracts of Isodictya erinacea, I. toxophila, Mycale (Oxymycale) acerata, and Cephalodiscus sp. in the mouse macrophage cell line RAW 264.7. Cytotoxicity (MTT method) and amount of inflammatory mediators released:

$\mathrm{PGE}_{2}, \mathrm{LTB}_{4}$, and IL-1 $\beta$, for each concentration tested $(250,125,50 \mu \mathrm{g} / \mathrm{mL})$, LPS control, and the reference anti-inflammatory drug dexamethasone (DX). B indicates the non-stimulated cell control. Statistical significance (ANOVA followed by Dunnett's test): ${ }^{*} P<0.05,{ }^{* *} P<0.01$, with respect to LPS control.

exhibit potent cytotoxicity toward murine P388 lymphocytic leukemia cell line (Rudy et al., 2008). In fact, cephalostatin 1 proved to be one of the most powerful cancer cell growth inhibitors (Moser, 2008). However, no Cephalodiscus species from the Southern Ocean had been tested for cytotoxic properties before our study and there are no molecules isolated so far (Avila et al., 2008).

Four species were not cytotoxic at the concentrations tested. The sponges Isodictya erinacea and Homaxinella cf. balfourensis have been previously tested and no cytotoxic activity was found (McClintock et al., 1990; Turk et al., 2013). Similarly, to the polyketide isolated from Synoicum adareanum, palmerolide A, which presented no cytotoxicity against several cell lines, in our study the macrophages RAW 264.7 were not affected by the different concentrations of the extracts tested (Diyabalanage et al., 2006). Likewise, several polyunsaturated acids with hemolytic activity have been isolated from individuals of Salpa thompsoni (Mimura et al., 1986).

The species providing the best results for avoiding the release of inflammatory mediators at non-cytotoxic concentrations were the hemichordate Cephalodiscus sp., and the sponges Isodictya erinacea, I. toxophila, and Mycale (Oxymycale) acerata. Since inflammation is caused by the release of chemicals from tissues and migrating cells, as mentioned above, we may conclude that the active extracts could be useful in avoiding inflammation and pain. Thus, these extracts possess promising molecules with anti-inflammatory activity, potentially useful in pharmacology. Finally, our study shows that Antarctic benthic invertebrates may have a great value as a source of lead compounds with potential pharmaceutical applications, such as painkillers. For this reason, it will be very interesting to isolate and to test the isolated molecules responsible of the release-avoidance of inflammatory mediators, which might provide future anti-inflammatory drugs.

\section{ACKNOWLEDGMENTS}

The authors wish to thank J. Vázquez, J. Cristobo, L. NúñezPons, and S. Taboada for field and laboratory support. Thanks are due to Prof. W. Arntz and the crew of the R/V of Polarstern for allowing our participation in the Antarctic cruise ANT XXI/2 (AWI, Bremerhaven, Germany). Funding was provided by the Spanish government through the ACTIQUIM Projects (CGL2004-03356/ANT, CGL 2007-65453/ANT, and CTM2010$17415 / \mathrm{ANT}$ ) and by the pharmaceutical company Bioibérica. 


\section{SUPPLEMENTARY MATERIAL}

The Supplementary Material for this article can be found online at: http://www.frontiersin.org/journal/10.3389/fmars.2014.

\section{4/abstract}

\section{REFERENCES}

Albericio, F., Álvarez, M., Cuevas, C., Francesch, A., Pla, D., and Tulla-Puche, J. (2010). "The sea as a source of new drugs Fernando," in Molecular Imaging for Integrated Medical Therapy and Drug Development, eds N. Tamaki and Y. Kuge (Tokyo: Springer Japan), 237-249.

Avila, C., Taboada, S., and Núñez-Pons, L. (2008). Antarctic marine chemical ecology: what is next? Mar. Ecol. 29, 1-71. doi: 10.1111/j.1439-0485.2007.00215.x

Blunt, J. W., Copp, B. R., Keyzers, R. A., Munro, M. H. G., and Prinsep, M. R. (2013). Marine natural products. Nat. Prod. Rep. 30, 237-323. doi: $10.1039 / \mathrm{c} 2 \mathrm{np} 20112 \mathrm{~g}$

Diyabalanage, T., Amsler, C. D., McClintock, J. B., and Baker, B. J. (2006). Palmerolide A, a cytotoxic macrolide from the antarctic tunicate Synoicum adareanum. J. Am. Chem. Soc. 128, 5630-5631. doi: 10.1021/ja0588508

Faulkner, D. J. (1995). Chemical riches from the ocean. Chem. Br. 31, 680-684.

Huang, Y. M., McClintock, J. B., Amsler, C. D., Peters, K. J., and Baker, B. J. (2006). Feeding rates of common Antarctic gammarid amphipods on ecologically important sympatric macroalgae. J. Exp. Mar. Biol. Ecol. 329, 55-65. doi: 10.1016/j.jembe.2005.08.013

Jha, R. K., and Zi-rong, X. (2004). Biomedical compounds from marine organisms. Mar. Drugs 2, 123-146. doi: $10.3390 / \mathrm{md} 203123$

Kijjoa, A., and Sawangwong, P. (2004). Drugs and cosmetics from the sea. Mar. Drugs 2, 73-82. doi: 10.3390/md202073

König, G. M., Kehraus, S., Seibert, S. F., Abdel-Lateff, A., and Müller, D. (2006). Natural products from marine organisms and their associated microbes. Chembiochem 7, 229-238. doi: 10.1002/cbic.200500087

Korbut, R., and Guzik, T. J. (2011). "Inflammatory Mediators and Intracellular Signalling," in Principles of Immunopharmacology, $3 r d$ Edn., eds F. P. Nijkamp and M. J. Parnham (Basel: Birkhäuser). doi: 10.1007/978-3-0346-0136-8_7

Laturnus, F., Wiencke, C., and Klöser, H. (1996). Antarctic macroalgae - sources of volatile halogenated organic compounds. Mar. Environ. Res. 41, 169-181. doi: 10.1016/0141-1136(95)00017-8

Lebar, M. D., Heimbegner, J. L., and Baker, B. J. (2007). Cold-water marine natural products. Nat. Prod. Rep. 24, 774-797. doi: 10.1039/b516240h

Mayer, A. M. S., Rodríguez, A. D., Berlinck, R. G. S., and Fusetani, N. (2011). Marine pharmacology in 2007-8: marine compounds with antibacterial, anticoagulant, antifungal, anti-inflammatory, antimalarial, antiprotozoal, antituberculosis, and antiviral activities; affecting the immune and nervous system, and other miscellaneous mec. Comp. Biochem. Physiol. C Toxicol. Pharmacol. 153, 191-222. doi: 10.1016/j.cbpc.2010.08.008

McClintock, J. B., Heine, J., Slattery, M., and Weston, J. (1990). Chemical bioactivity in common shallow-water Antarctic marine invertebrates. Antarct. J. U. S. 25, 204-206.

Mimura, T., Okade, M., Satake, M., Nakanishi, T., Inada, A., Fujimoto, Y., et al. (1986). Fatty acids and sterols of the tunicate, Salpa thompsoni, from the Antarctic Ocean: chemical composition and hemolytic activity. Chem. Pharm. Bull. 34, 4562-4568. doi: 10.1248/cpb.34.4562

Moser, B. R. (2008). Review of cytotoxic cephalostatins and ritterazines: isolation and synthesis. J. Nat. Prod. 71, 487-491. doi: 10.1021/np070536z

Newman, D. J., and Cragg, G. M. (2012). Natural products as sources of new drugs over the 30 years from 1981 to 2010. J. Nat. Prod. 75, 311-335. doi: $10.1021 / \mathrm{np} 200906 \mathrm{~s}$

Rivera, P. (1996). Plastoquinones and a chromene isolated from the Antarctic brown alga Desmarestia menziesii. Bol. Soc. Chil. Quim. 41, 103-105.

Rudy, A., López-antón, N., Dirsch, V. M., and Vollmar, A. M. (2008). The cephalostatin way of apoptosis. J. Nat. Prod. 71, 482-486. doi: 10.1021/ np070534e

Taboada, S., Núñez-Pons, L., and Avila, C. (2012). Feeding repellence of Antarctic and sub-Antarctic benthic invertebrates against the omnivorous sea star Odontaster validus. Polar Biol. 36, 13-25. doi: 10.1007/s00300-0121234-z

Turk, T., Ambrožič Avguštin, J., Batista, U., Strugar, G., Kosmina, R., Čivović, S., et al. (2013). Biological activities of ethanolic extracts from deep-sea Antarctic marine sponges. Mar. Drugs 11, 1126-1139. doi: 10.3390/md11041126

Conflict of Interest Statement: The authors declare that the research was conducted in the absence of any commercial or financial relationships that could be construed as a potential conflict of interest.

Received: 21 May 2014; accepted: 30 June 2014; published online: 22 July 2014. Citation: Moles J, Torrent A, Alcaraz MJ, Ruhí R, and Avila C (2014) Antiinflammatory activity in selected Antarctic benthic organisms. Front. Mar. Sci. 1:24. doi: 10.3389/fmars.2014.00024

This article was submitted to Marine Biotechnology, a section of the journal Frontiers in Marine Science.

Copyright () 2014 Moles, Torrent, Alcaraz, Ruhí, and Avila. This is an open-access article distributed under the terms of the Creative Commons Attribution License (CC BY). The use, distribution or reproduction in other forums is permitted, provided the original author $(s)$ or licensor are credited and that the original publication in this journal is cited, in accordance with accepted academic practice. No use, distribution or reproduction is permitted which does not comply with these terms. 